\title{
Folk-Medicine in County Cork
}

\section{Kate Lawless Pyne \& Pandit Bhagwan Das Sarma}

To cite this article: Kate Lawless Pyne \& Pandit Bhagwan Das Sarma (1897) Folk-Medicine in County Cork, Folklore, 8:2, 179-187, DOI: 10.1080/0015587X.1897.9720413

To link to this article: http://dx.doi.org/10.1080/0015587X.1897.9720413

$$
\text { 曲 Published online: } 14 \text { Feb } 2012 .
$$

Submit your article to this journal $\pi$

LII Article views: 1

Q View related articles $₫$ 


\section{MISCELLANEA.}

\section{Folk-Medicine in County Cork.}

Whooping (or Chin) Cough.-If you see a man riding by on a white or piebald horse, anything he tells you to do will effect a cure.

You say, "Wisha, man on the white (or piebald) horse, for God's sake, do you know any cure for the chin cough ?"

He: " Faith then, I don't know of any cure, unless to take the chile fastin' to the four cross-roads and give him his feedin' there for four mornings running " (i.e. following).

This was tried on a child who had had a "doctor's bottle," which failed to cure : hence the charm, which proved most efficaciousa fact vouched for by persons who know the mother. She lives in Lower Dripsey. Date of cure, June, i 896 .

Another.-A "Boo" in a bottle.-Catch a blue-bottle fly, put it in a corked (?) bottle, and as the fly gets weaker and dies off, so will the cough take its departure. Vouched for and seen by my informant.

Another.-The "Gossip," i.e. the godfather of the child, without being told by any one of the child's people, but by his own vile inspiration, must steal, i.e. cut off, the ear of his neighbour's living goat close to the head, make a hole in it with a fork, and pass a string through it; this is tied round the child's neck, and is meant to be sucked by the child.

This was tried on Han Twoomey, Mary L.'s factotum, about thirty years ago. She told me about it, and her cousin, wife of our ploughman, remembers well seeing this loathsome object round the child's neck for about three months. Truly the native Irish are savages.

Another.-Get a mare donkey in milk, and have a person standing on each side of the animal. One passes the child under the body of the donkey to the other, who returns it over the back. Do this nine times for three mornings fasting. 
This was tried with a female donkey of C. L.'s on two of her labourer's children, who are grown man and woman now, and the donkey is alive and kicking.

Another.-Find a married couple, who are first cousins; if one gives the child solid food and the other liquid, in the name of the Trinity, for three mornings fasting, the child will recover quickly.

Charm for Aptha or Thrush. (This disease is very common with children.)-Get a gander and make him breathe or hiss into the child's mouth; or if this cannot be done, get a person born after his or her father's death, and he or she must blow down the child's throat for four mornings fasting, in the name of the Trinity.

$\Lambda$ garden boy we had here earned many shillings by blowing into the mouths of children.

The Cottage, Coachford, Co. Cork.

Kate Lawless Pyne.

\section{A Bukial Superstition in County Cork.}

When two corpses come to the same graveyard the same day, the last to enter will be employed drawing water to wet the lips of all the souls in Purgatory. Two persons were to be buried at South Kilmurry the same day, and the relatives of one determined to be first. So they locked the gate and gave the key to the sexton with orders to let no one in. 'The two funerals arrived together, each trying to be first, but the gate was locked. The first tried to put their coffin over the ditch, but number two struck them, so they put down their coffin and went in search of the key. The moment their backs were turned the others threw their own coffin feet first over the wall, thus securing the entret to the churchyard, and leaving the others to get. in as best they could. They gave a wild cheer as they got in, the first intimation their rivals had of what happened. (Told to me by one present at funeral.)

Kate Lawless Pynli. 


\section{a Folktale from Kumaon.}

While travelling in Kumaon, in the Himalaya mountains, some time ago, I came to a stage bungalow near the village of Bans, and some little boys came to the bungalow. I asked them to tell some stories, and the first one that was related resembled so much, in its main details, the story of "The Big Claus and the Little Claus " in Hans Andersen's fairy tales, that I took it down. One great difference between them is that in Hans Andersen there are only two brothers, while in the story there are eight. But the seven so figure together and act in a body that they have practically no separate individual existence. The creaking hide and the river, \&c., \&c., are the same, and, making allowance for differences in local colouring, the two seem to have a very striking similarity. I am not a member of the Folk-Lore Society, but taking an interest in the study of folklore, I venture to send the story to you, and hope it may be interesting as an item of evidence, however trifling, in support of the theory that the folktales of Europe and India could be traced to a common origin.

\section{Pandit Bhagwan Das Sarma.}

\section{Chhatarpur State, Central India.}

Once in a town lived eight brothers. The youngest of them looked a silly sort of fellow, and his brothers thought him a fool. Their father died, and they divided the patrimony among themselves, and gave the youngest much less than his due. He bought a bull-buffalo, while they bought cow-buffaloes. Every night he carried the buffalo on his shoulders to his brothers' field and grazed him there. In the morning, when the brothers came to the field, they found the plants eaten. But as there were no marks of an animal's feet in the field they could not detect the poacher. One day the animal drank too much water, and became so heavy that he could not carry it. He left him in the field, and allowed him to graze there at large. The brothers had watered the field that very day, and the soil was so moist that the feet of the buffalo left deep marks in the field. When they went there next morning they saw the plants eaten, and the deep marks of the buffalo's feet. Straightway they ran to their youngest brother, and showered blows on his poor buffalo till it died. He begged 
his brothers to leave the carcase of his dear beast for him. He then pulled of the skin and turned it into a hide, and putting it on his shoulders started for a neighbouring market-town to sell it. On his way he was caught in the rain, and the hide became dripping wet. At length he reached a sort of cave, and, feeling tired, put the hide at the mouth of it. Inside the cave were robbers who had come there to divide their booty. The hide was wet, and when he put it at the mouth of the cave it made a noise and darkened the cave. The robbers thought they had been found out, and ran away, leaving the booty to the lucky man. Entering the cave, he found gold and silver and precious stones. At once he put them all into a bundle, and, leaving the hide there, took his way home with his newly-gained riches. Now he was a rich man, and his brothers were very jealous of him. One day they went to him, and asked him what he had done with the hide. He told them that he had sold it at a very high price to a man who lived in the Brahmans' quarter in a neighbouring town. They ran home at once and killed their buffaloes, and, carrying their hides on their shoulders, went to sell them in the Brahmans' quarter their brother had pointed out. Arriving there they called out loudly: "Buffalo-hides for sale !" Great was the surprise of the Brahmans on hearing such words, and coming out of their houses they gave them a sound beating for bringing such unclean things near their houses. They were very angry with their brother, and hurried back as fast as they could, and going straight to his house set fire to it. The house was soon reduced to ashes, but the brother escaped with his life. He collected the ashes in a bag, and putting the bag on his head made his way to a neighbouring town. He went to the palace of the Raja, and after exchanging greetings with the porter at the gate, said to him: "I have brought jewels and other valuable presents from our Raja to your Raja; please look after the bag, I am going out to wash, and shall come back very soon. But pray, allow no one to touch the bag in my absence, or the valuables will turn into ashes." Having said this, he went away, and after strolling about for some time came back and opened the bag. He had scarcely half-opened it when he began to cry "I am ruined, I am ruined. I told you beforehand that if any body touched it in my absence it would turn into ashes, and so it has happened. Now what shall I do? I have lost thousands 
of rupees' worth ; somebody must repay me." A crowd soon gathered on the spot, but the man would not listen to any one; and as the crowd increased his cries became more piteous, and with sobs he told the multitude how he had been ruined. At length the affair reached the ears of the Raja, who was very kindhearted and generous. He ordered the whole amount to be paid to the man. He quickly put the money in the bag, and throwing it on his shoulders hastened home. The brothers heard of his wealth, and came to ask him how he got it. "I sold the bag of ashes," said he, "to a merchant who deals in flour. He stood in great need of ashes, as he adulterates his flour with ashes, and thus makes a great profit." Hardly had he uttered these words before his brothers ran home and set their houses on fire. They then gathered the ashes, put them in bags, and each one carrying a bag on his shoulders went to the neighbouring market. At a grocer's shop they opened the bags and began to pour out the contents into the heaps of flour exposed for sale. When the grocer saw it he was very angry, and cried: "Why, fools! what are you doing?" "We are mixing ashes with your flour," said they. Whereupon the grocer got up and, rushing upon them, kicked them out of his shop. They were now full of wrath against their brother, and determined to put an end to his life. Hurrying to his house, they caught hold of him and shut him up in a sack. They put the sack on their shoulders and carried it to the Ganges. When they reached the middle of the stream they threw the sack down into the river. By the man's good luck the sack floated ashore and rested against a bridge by the public way. A banker's son mounted on a good horse was going home with a bag full of jewels and gold and silver coins. When he approached the sack he heard a voice, saying: "Oh 1 I enjoy the sight of the three worlds." The banker's son advancing nearer, said: "My friend, can I enjoy the sight too?" "Yes," said the voice. "How ?" asked the banker's son. "If you only come here," was the reply The banker's son opened the mouth of the sack and the man came out. "Go into the sack," said he to the banker's son, and when he had got in he closed up its mouth. He then mounted the horse and galloped home with his treasure. The brothers were amazed to see him, and asked him where he got the horse. "Our parents," said he, "gave me the horse; they live inside the Ganges. They love you much more than me because 
you are their elder children, and would give you immense riches if you were to sec them." "How can we see them?" asked they. "It is very casy," said he. "I will be your guide. Take a dog with you and let him go into the Ganges in front of you; follow the dog to the spot he leads you to and you will see our parents." They all left the house taking their dog with them. When they reached the bridge the youngest brother pointed out to them with his hand the spot where he said he met his parents. First the dog went into the stream and then the seven brothers. The youngest remained on the bank. The dog continued moving his logs all the while he was swimming, and the brothers followed him till they were drowned.

['This particular form of the story is not very common, but it is found in Wales and Ireland. See Jacobs, Celtic Fairy Tales, pp. 47,247 ; Folklore, vol. iii. p. 126,-En.]

\section{Plougfi Monday.}

The following account of Plough Monday at Witchford, in the Isle of Fily, was written down by a young woman who came from that neighbourhood, and sent to Mr. J. G. Frazer, by whom it is kindly forwarded :

"In the village of Witchford, situated in the Isle of Ely, in the evening on the second Monday of January, several young men form a party. They go together and get some one to lend them a plough and some whips; and then they get some straw and put on their backs; and then they black their faces, and one of them dresses up as an old woman; and then two of them draw the plough and one takes hold of the handles, and two of them have brooms with them and two of them are cadgers, and the rest of them have whips and go cracking at the peoples' doors and keep calling out: "Whon! Whon!' and when the people come out to look at them they all set to and have a dance and then ask you for money, and if you do not give them any they pull up your scraper. That is how they go on until they have been all over the village, and then they all go to some one's housc and suend the money they get given to them. They have bread and cheese and beer and singing songs all the rest of the evening; and that is how they end the evening on Plough Monday." 


\section{Folk-Mmdicine in Orio.}

Mrs. George $\Lambda$. Stanbery, writes from $\Lambda$ dair Arc Terrace, Zanesville, Ohio, U.S.A., as follows:

In Somerset, Perry County, Ohio, lived an old German woman, by the name of Mrs. Harper, who was said to do wonders in curing diseases; and as I was a small child at that time, these things, talked about in my presence, made a great impression on my mind, but when most needed some of the most important points had fled from my memory. So I wrote to a relative of Mrs. Harper's, a Mr. Samuel Poorman, now of San Francisco, but formerly of Somerset, Perry County, Ohio, thinking that he or some of his family might be able to give me some information. I had also written to a friend in Somerset, asking her to find out for me about the measurements required in the cure for the "decay of the flesh in children." The two letters came together, and both had the desired information. Mrs. Benoni Beckwith, of Somerset, still keeps up the practice, and she very willingly gave me her method, which, by the way, is exactly the same as that used by Grandmother Harper; and as Mr. Poorman has given me other valuable and (to me) new cures, I will quote from his letter. I am sorry that I shall be obliged to wait to hear from him before submitting a very important cure for relieving persons of pain who have been burned or scalded. He sent me the secret on a separate paper, because it loses its charm by being too generally known ; but he did not say whether or not I might send it to you with the others, so I must wait for permission. $A$ man can give the secret to a woman, or vice versi ; but a woman must on no account give it to a woman. As I am now in possession of the charm I am waiting for some one to burn himself, when I will try my powers.

Grandmother Harper's Cure for the Decay of the Flesh.,-The child must be brought on three successive mornings, and stripped of all its clothing. Then with a linen string measure the length of the foot seven times. With this string measure the length of the body, commencing at the crown of the head and follow down the back to the tip of the heel. If the length of the child is less than seven lengths of the foot, the child is affected with decay. In this event a loop is formed with this string by holding its ends together between the thumb and forefinger. The loop is then passed over 
the child three times from the head to the feet. The string is wound around the hinge of a door or gate, and as the string is worn away the child is restored to health. Mrs. Harper put the string on a wooden hinge. These were much used at that time on gates and barn doors. I presume an iron hinge would answer the same purpose.

Mrs. John Wiseman's Cure for the Thrush (Sore Mouth)."Three straws were obtained from the barnyard, which were broken or cut into equal lengths of about three inches. These were bound together in the middle with a string. The bundle thus formed was then passed between the lips of the afflicted child three times from right to left. The bundle of straws was then buried in the manure pile in the barnyard, where it remained until the next 'trying,' as it was called. In severe cases the operation, with the same bundle of straws, was repeated three times at intervals of half an hour. This whole process with the same straws was repeated in twelve hours, and again in twenty-four hours, making in all nine 'tryings.' This would suffice for the most obstinate cases. In moderate cases there would be three 'tryings' at intervals of twelve hours. Whether in the various resurrections of the bundle of straws there was any cleansing I do not know, but I presume not.

"Sallie Jackson, my sister's oldest child, when an infant, was so badly afflicted with Thrush that blood oozed from her mouth whenever she opened it. Mrs. Wiseman operated on her. On the first 'trying' blood flowed from her mouth in a stream, on the second 'trying,' in half an hour, a very little blood was seen, and on the third there was no blood. My sister was directed to return the following morning (twelve hours later), but when morning came she found the child's mouth entirely well I There was no further treatment, and no more 'Thrush.

"Mrs. Wiseman treated a Mrs. Aumentrout, of Thornville, Ohio, to whose breasts the disease had been communicated by her child. They were in such condition that the doctors had decided to remove them to save her life. The treatment was the same as for the child, passing the straws over her breasts as they were passed through the lips of the child. In this case there were three trials, or 'tryings,'at half-hour intervals, which were repeated in twelve and in twenty-four hours. At the last of these tryings no signs of Thrush remained.

"When a child, my oldest sister was badly aflicted with 
Phthisic. A shoemaker by the name of Dennis treated her for it in the following manner. Measuring her height against the doorcasing, he bored a hole with an augur at that point, took a lock of hair from her head, placed it in the hole, and then filled the hole with a neat-fitting pin of wood. She never after had the Phthisic. I cannot say whether there was any wheezing about that door-casing or not afterwards.

"Io Cure Enlargement of the Spleen.-Pass the afflicted child from east to west, as the sun goes, around the leg of a chair or a table three times.

"To Cure a Wen.-When an entire bone is found lying on the ground (one that has not been broken or cut) rub the bone over the wen, and then replace it in the same position it was in when found.

"The late H. C. Trainor, of Sacramento City, Cal., cured warts by tying three knots in a thread over the wart. The thread did not have to touch the wart, but was held in such a way that the loop for the knot was directly over the wart until drawn into a knot. The thread was then thrown away, and in a very few days the wart would disappear.

"William Dugan, who used to work for my father, had a great reputation for stopping hemorrhages, but I know nothing of the process. You should be able to learn something of it from the Hammonds of Somerset."

Then Mr. Poorman says : "I herewith enclose a memorandum explaining sister Mattie's method for the relief of burns. I make it separate, because of the secrecy necessary and the method of communicating it from one to another. It will not do for a person to tell it to one of the same sex. Mattie has given it to me, and I give it to you. I think those claiming to possess these powers hold, among other things, that the power is lost if the method is too often communicated to others." I have written to-day to Mr. Poorman for permission to publish the Burn Remedy.

Mr. Poorman says that "on one occasion my brother-in-law had a horse that was bleeding profusely from a wound, and all efforts to stanch the blood were unsuccessful. $\Lambda$ s a last hope for saving the life of the horse he insisted on Mattie's (his wife) trying her burn remedy. She did so, only varying the latter part to suit the case, and they both say the flow of blood ceased immediately." 